\title{
Assessing the adrenal axis by the glucagon stimulation test in children with idiopathic growth hormone deficiency
}

Ocena osi podwzgórze-przysadka-nadnercza za pomocą testu stymulacji glukagonem u dzieci z idiopatycznym niedoborem hormonu wzrostu

\author{
${ }^{1}$ Ach Taieb, ${ }^{1}$ Ben Abdelkarim Asma, ${ }^{1}$ Hasni Yosra, ${ }^{1}$ Maaroufi Amel, ${ }^{1}$ Kacem Maha, ${ }^{1}$ Chaieb Molka, \\ ${ }^{2}$ Zaouali Monia, ${ }^{1}$ Ach Koussay
}

${ }^{1}$ Department of Endocrinology, University Hospital of Farhat Hached Sousse, Tunisia

${ }^{2}$ Department of Physiology, University Hospital of Farhat Hached Sousse, Tunisia

\begin{abstract}
Approximately $30 \%$ of children with idiopathic growth hormone deficiency (IGHD) also suffer from other pituitary hormone deficiencies. Of children with IGHD, approximately $10 \%$ are unable to generate appropriate ACTH levels in response to stress. This study was prospectively designed to test the integrity of the adrenal axis in patients with an established diagnosis of IGHD using the glucagon stimulation test (GST). The study population comprised 39 patients with established childhood-onset IGHD. The diagnosis of GHD was established on the basis of failure of $\mathrm{GH}$ to increase over $10 \mathrm{ng} / \mathrm{ml}$ after two stimulation tests. The GST was performed by intramuscular injection of $1 \mathrm{mg}$ glucagon. The criteria followed to define adrenal deficiency was cortisol less than $167 \mathrm{ng} / \mathrm{l}$ in response to GST. The mean peak blood glucose level was $8.64 \pm 1.71 \mathrm{mmol} / \mathrm{l}$. Analysing the cohort using the cut-off of $167 \mathrm{ng} / \mathrm{ml}$ to define adrenal insufficiency under GST, there were $25.64 \%$ of children diagnosed: $20 \%$ among males and $35.7 \%$ among females. Subjects with $\mathrm{GH}$ and ACTH deficiency had a mean peak $\mathrm{GH}$ of $2.07 \pm 1.79 \mathrm{ng} / \mathrm{ml}$ - significantly lower than GH peak of children with IGHD alone $(p<0,001)$. The frequency of children with combined somatotroph and corticotroph deficiencies with a $\mathrm{GH}$ peak $<3 \mathrm{ng} / \mathrm{ml}$ was $21 \%(p<0,001)$. The current study identified a prevalence of adrenal insufficiency of $25.64 \%$, which could predict greater risk for children if untreated, especially because a substantial proportion of patients do not present clinical symptoms.
\end{abstract}

Key words:

growth hormone deficiency, idiopathic growth hormone deficiency, glucagon stimulation test, adrenal insufficiency, cortisol, GH, children.

\begin{abstract}
Streszczenie
Około 30\% dzieci z idiopatycznym niedoborem hormonu wzrostu (IGHD) cierpi również z powodu innych niedoborów hormonów przysadki mózgowej. Około 10\% dzieci z IGHD nie jest w stanie wytworzyć odpowiednich stężeń ACTH w odpowiedzi na stres. Prospektywnym celem niniejszej pracy było zbadanie integralności osi podwzgórze-przysadka-nadnercza u pacjentów z ustalonym rozpoznaniem IGHD przy użyciu testu stymulacji glukagonem (GST). Badaną populację stanowiło 39 pacjentów z rozpoznaną IGHD w wieku dziecięcym. Rozpoznanie GHD ustalono na podstawie dwukrotnej odpowiedzi deficytowej (GH poniżej $10 \mathrm{ng} / \mathrm{ml}$ ) w teście stymulacji. Stymulację glukagonem przeprowadzono przez domięśniową iniekcję $1 \mathrm{mg}$ glukagonu. Kryteriami stosowanymi w celu określenia niedoczynności kory nadnerczy było stężenie kortyzolu poniżej 167 ng/l w odpowiedzi na GST. Średnie szczytowe stężenie glukozy we krwi wynosiło 8,64 $\pm 1,71$ mmol/l. Analizując kohortę przy użyciu wartości odcięcia 167 ng/ml w celu określenia niewydolności kory nadnerczy w ramach GST, zdiagnozowano 25,64\% dzieci: 20\% płci męskiej i 35,7\% płci żeńskiej. Pacjenci z niedoborem GH i ACTH mieli średni szczyt GH 2,07 $\pm 1,79 \mathrm{ng} / \mathrm{ml}$ znacząco niższy niż szczyt GH u dzieci z samym IGHD ( $p<0,001)$. Dzieci z łączonymi defektami somatotroficznymi i kortykotropowymi ze szczytem GH $<3$ ng/ml stanowiły 21\% ( $p<0,001)$. Stwierdzono występowanie niewydolności nadnerczy u 25,64\%, co może prognozować większe ryzyko dla dzieci, jeśli pozostaną one nieleczone, zwłaszcza że znaczna część pacjentów nie ma objawów klinicznych.
\end{abstract}

Słowa kluczowe:

niedobór hormonu wzrostu, idiopatyczny niedobór hormonu wzrostu, test stymulacji glukagonem, niewydolność kory nadnerczy, kortyzol, GH, dzieci. 


\section{Introduction}

Growth hormone deficiency (GHD) occurs in approximately one in 3000 to one in 4000 children and is caused by a heterogeneous group of abnormalities [1]. Most cases are classified as idiopathic GHD (IGHD), which is thought to result from abnormal hypothalamic production of GHRH or from disturbed pituitary secretion of GH [2]. Other aetiologies of GHD include central nervous system tumours, brain malformations, cerebral surgery, or radiation therapy. Growth hormone therapy has been used for years and has proven efficacy [3].

Approximately $30 \%$ of children with IGHD also suffer from other anterior pituitary hormone deficiencies [2]. Of children with IGHD, approximately $20 \%$ have insufficient pituitary TSH production, and $10 \%$ are unable to generate appropriate ACTH levels in response to stress $[4,5]$. The literature suggests that it is extremely rare for children with GHD to have ACTH deficiency without concomitant TSH deficiency or an organic brain lesion [6].

However, although clinically asymptomatic [7], the hypothalamic-pituitary-adrenal axis (HPA) of these patients cannot appropriately react to stressful stimuli, with potentially lifethreatening consequences. Thus, evaluation of the integrity of the HPA is essential in patients with GHD.

Although the diagnosis of overt adrenal failure is generally straightforward, identification of those asymptomatic patients with subtle dysfunction of the HPA axis is still a diagnostic challenge. The HPA axis response to insulin hypoglycaemia (ITT) is still considered the gold standard in the evaluation of suspected adrenal insufficiency [8]. Furthermore, ITT is contraindicated in infants, especially those with a history of seizures [9]. Patients with multiple pituitary hormone deficiencies experienced severe hypoglycaemia during ITT, and occasional deaths in children have been reported with the use of such tests [10]. Therefore, alternative tests to evaluate the HPA have been proposed, such as the glucagon stimulation test (GST) [11]. The GST allows the evaluation of the somatotrophic axis, such as insulin hypoglycaemia, but with fewer and less adverse effects [12]. The usefulness of the glucagon test has been evoked for a long time, but its accuracy in the evaluation of the corticotropic axis must be determined according to the teams and methods of testing and dosing [13].

We have recently identified the cortisol cut-off under GST in a prospective cohort, so it may lead us to identify the adrenal insufficiency in this current study [14].

This study was prospectively designed to test the integrity of the adrenal axis in patients with an established diagnosis of IGHD using GST.

\section{Material and methods}

\section{Patients}

The study population comprised 39 patients with established childhood-onset IGHD. All the children were in a prepubertal state and did not have any medical history.
The diagnosis of GHD was established on the basis of failure of growth hormone $(\mathrm{GH})$ to increase over $10 \mathrm{ng} / \mathrm{ml}$ after two stimulation tests (ITT and GST) [4]. In all patients, heights were under -2 standard deviations (SD), and insulin-like growth factor-1 (IGF-1) concentrations were lower than those of agematched normal subjects.

Patients with any diagnoses that could possibly explain their GHD, such as brain tumour, cranial irradiation, hydrocephalus, Prader-Willi syndrome, chromosomal abnormality, and periventricular leukomalacia were excluded. All patients underwent MRI to exclude any pituitary abnormalities.

\section{Evaluation of HPA by dynamic tests}

The ITT and GST were performed on separate days after an overnight fast. Glucocorticoids were discontinued at least $24 \mathrm{~h}$ before testing. The maximum interval between the two dynamic tests was seven days. Further assessment of anterior pituitary function was done by baseline hormonal testing as well as by provocative tests as required.

The GST was performed by intramuscular injection of $1 \mathrm{mg}$ glucagon. Blood samples for measurement of cortisol and glycaemia were obtained in the basal state and 30,60, 90, 120, 150, 180, and 210 minutes after glucagon injection. All patients were asked to report side-effects associated with this test, and anti-emetics were administered at the discretion of the supervising physician.

The criterion generally followed to define adrenal deficiency during this time period was a cortisol of less than $167 \mathrm{ng} / \mathrm{l}$ in response to GST [14]. First morning cortisol and ACTH levels were not used for diagnosis due to high variability.

\section{Assessment of hormone levels}

Serum GH levels were measured using the IRMA method with a commercially available kit (Beckman Coulter) with a sensitivity of $0.1 \mathrm{ng} / \mathrm{ml}$; intra-assay and inter-assay coefficient variation were $1.5 \%$ and $14 \%$, respectively.

Serum cortisol levels were measured using the radioimmunoassay method with a commercially available kit (Beckman Coulter) with a sensitivity of $7 \mathrm{ng} / \mathrm{ml}$; intra-assay and inter-assay coefficient variations were $2.8 \%$ and $5.3 \%$, respectively.

\section{Statistical analysis}

Statistical analysis was performed using the IBM SPSS Version 23.0 (IBM Inc) program. Correlation analysis was conducted with Pearson's and Spearman's analysis for parametric and nonparametric variables, respectively. Chi-square tests were used for qualitative variables. Data were expressed as mean \pm standard deviation. A $p$ value $<0.05$ was considered as statistically significant.

\section{Results}

At evaluation the mean age of the 39 children was 9.74 \pm 2.65 years (extremes: 6 years and 14 years): 25 boys $(64.1 \%)$ and 14 girls (35.9\%). The age of the break in the growth curve in children was $10.43 \pm 2.78$ years, with a mean bone age of 
$10.03 \pm 2.94$ years. The mean height was $154.33 \pm 4.22 \mathrm{~cm}$, with a standard derivation of -2 SD for $53.3 \%$ and -3 SD for 46.7\%. The variabilities between genders are shown in Table I.

\section{Cortisol evaluation}

The mean peak blood glucose level was $8.64 \pm 1.71 \mathrm{mmol} / \mathrm{l}$ and was found most frequently $(69.2 \%)$ during the $30^{\text {th }}$ minute $(p<0,001$; Table II). The mean glycaemic nadir was 3.75 $\pm 0.92 \mathrm{mmol} / \mathrm{l}$ and was most frequently found during the $120^{\text {th }}$ minute $(p<0,001)$. The mean baseline cortisol level was 97.33 $\pm 45.62 \mathrm{ng} / \mathrm{ml}$ with a peak level of $179.1 \pm 75.05 \mathrm{ng} / \mathrm{ml}$, most commonly occurring (43.6\%) in the $180^{\text {th }}$ minute $(p<0,001)$. Analysing the cohort using the cut-off of $167 \mathrm{ng} / \mathrm{ml}$ to define adrenal insufficiency under GST, there were $25.6 \%$ of the children diagnosed: $20 \%$ among males and $35.7 \%$ among females (Table I).

\section{Growth hormone evaluation}

The mean $\mathrm{GH}$ peak was $4.86 \pm 4.09 \mathrm{ng} / \mathrm{ml}$ and was found most frequently $(28.2 \%)$ during the $120^{\text {th }}$ minute $(p=0.02)$. Children with a partial response $(\mathrm{GH}>5 \mathrm{ng} / \mathrm{ml})$ comprised $51.3 \%$.

Table I. Clinical characteristics and comparison of tests between genders (mean \pm SD values)

\begin{tabular}{llll}
\hline & Males $(n=25)$ & Females $(n=14)$ & $p$ value \\
\hline Clinical characteristics & & & \\
\hline Age (years) & $9.48 \pm 2.64$ & $10.21 \pm 2.69$ & 0.09 \\
\hline Height $(-\mathrm{SD})$ & $165 \pm 3.66(-3.32 \pm 0.47)$ & $149 \pm 9.79(-3.75 \pm 0.88)$ & $<10^{-3}$ \\
\hline Body mass index & $19.56 \pm 4.24$ & $21.28 \pm 5.59$ & 0.08 \\
\hline Bone age $(-\mathrm{SD})$ & $9.88 \pm 3.24(-1.5 \pm 1.3)$ & $11 \pm 2.60(-1.4 \pm 1.1)$ & 0.06 \\
\hline Glucagon stimulation test & & & \\
\hline Peak cortisol $<167 \mathrm{ng} / \mathrm{ml}(\%)$ & $5(20 \%)$ & $5(35.7 \%)$ & 0.1 \\
\hline Basal cortisol $(\mathrm{ng} / \mathrm{ml})$ & $102.80 \pm 43.80$ & $87.57 \pm 48.81$ & 0.04 \\
\hline Peak cortisol $(\mathrm{ng} / \mathrm{ml})$ & $218.2 \pm 69.13$ & $177.21 \pm 90.89$ & 0.01 \\
\hline Delta cortisol increment $(\mathrm{ng} / \mathrm{ml})$ & $111.4 \pm 59.60$ & $89.29 \pm 61.73$ & 0.05 \\
\hline Peak GH $(\mathrm{ng} / \mathrm{ml})$ & $5.44 \pm 4.17$ & $3.82 \pm 3.87$ & 0.04 \\
\hline
\end{tabular}

Table II. Mean glycaemic ( $\mathrm{mmol} / \mathrm{l})$ and cortisol levels $(\mathrm{ng} / \mathrm{ml})$ and peak frequencies by time during GST in the study population

\begin{tabular}{|c|c|c|c|c|c|c|c|c|}
\hline Time (minutes) & TO & T30 & T60 & T90 & $\mathrm{T} 120$ & T150 & T180 & T210 \\
\hline $\begin{array}{l}\text { Glycaemic means } \\
(\mathrm{mmol} / \mathrm{ml})\end{array}$ & $\begin{array}{l}5.03 \\
\pm 0.66\end{array}$ & $\begin{array}{l}8.29 \\
\pm 1.31\end{array}$ & $\begin{array}{l}7.54 \\
\pm 2.34\end{array}$ & $\begin{array}{l}5.67 \\
\pm 2.39\end{array}$ & $\begin{array}{l}4.58 \\
\pm 1.69\end{array}$ & $\begin{array}{l}4.39 \\
\pm 1.34\end{array}$ & $\begin{array}{l}4.5 \\
\pm 1.06\end{array}$ & $\begin{array}{l}4.47 \\
\pm 1.03\end{array}$ \\
\hline $\begin{array}{l}\text { Hyperglycaemic peak } \\
\text { frequency, } n(\%)\end{array}$ & 0 & 27 (69.2) & $11(28.2)$ & $1(2.6)$ & 0 & 0 & 0 & 0 \\
\hline $\begin{array}{l}\text { Hypoglycaemic peak } \\
\text { frequency, } n(\%)\end{array}$ & 0 & 0 & 0 & $5(12.8)$ & $13(33.3)$ & $9(23.1)$ & $5(12.8)$ & $7(17.9)$ \\
\hline $\begin{array}{l}\text { Cortisol means } \\
(\mathrm{ng} / \mathrm{ml})\end{array}$ & $\begin{array}{l}97.33 \\
\pm 45.62\end{array}$ & $\begin{array}{l}110.79 \\
\pm 61.52\end{array}$ & $\begin{array}{l}105.71 \\
\pm 67.81\end{array}$ & $\begin{array}{l}106.58 \\
\pm 58.49\end{array}$ & $\begin{array}{l}128.33 \\
\pm 59.14\end{array}$ & $\begin{array}{l}161.66 \\
\pm 70.36\end{array}$ & $\begin{array}{l}179.1 \\
\pm 75.05\end{array}$ & $\begin{array}{l}164.82 \\
\pm 67.78\end{array}$ \\
\hline $\begin{array}{l}\text { Cortisol peak } \\
\text { frequency, } n \text { (\%) }\end{array}$ & 0 & $2(5.1)$ & $1(2.6)$ & $1(2.6)$ & $2(5.1)$ & $10(25.6)$ & $17(43.6)$ & $6(15.4)$ \\
\hline
\end{tabular}


Table III. Frequencies of GH peak in children with IGHD only and children with combined somatotroph and corticotroph deficiencies

\begin{tabular}{llll}
\hline GH $(\mathrm{ng} / \mathrm{ml})$ & $\mathrm{GH} 9.9-5.0$ & $\mathrm{GH} 4.9-3.0$ & $\mathrm{GH}<3.0$ \\
\hline IGHD only, $n(\%)$ & $17(43.58 \%)$ & $4(10.25 \%)$ & $8(20.51 \%)$ \\
\hline IGHD + adrenal insufficiency, $n(\%)$ & $1(2 \%)$ & $1(2 \%)$ & $8(21 \%)$ \\
\hline
\end{tabular}

Subjects with IGHD alone had a mean peak GH of 5.82 $\pm 4.24 \mathrm{ng} / \mathrm{ml}$, and $43.58 \%$ had a GH peak $>5 \mathrm{ng} / \mathrm{ml}(p<0,001)$.

Subjects with $\mathrm{GH}$ and ACTH deficiency had a mean peak $\mathrm{GH}$ of $2.07 \pm 1.79 \mathrm{ng} / \mathrm{ml}$ - significantly lower than $\mathrm{GH}$ peak of children with IGHD alone $(p<0,001)$. The frequency of children with combined somatotroph and corticotroph deficiencies with a GH peak $<3 \mathrm{ng} / \mathrm{ml}$ was 21\% ( $p<0,001$; Table III).

\section{Discussion}

As yet, few works have studied the association of adrenal insufficiency in the diagnosis of IGHD in children. Therefore, no specific recommendations exist regarding additional evaluation of anterior pituitary function in children diagnosed with IGHD. In the most common cases, the pituitary screening in short stature aims to diagnose hormonal causes of the growth break. Exploring the GHD is based on an inadequate response of the hormone to provocation by ITT or GST $[6,7]$.

The usefulness of the GST in the evaluation of the corticotropic axis has been evoked for a long time [11], and its accuracy leaves no doubt in view of the many international studies that validate and recommend it [15]. Due to its mild side effects and the possibility of coupled dosing with $\mathrm{GH}$, the glucagon test is a valid alternative for a contraindication to the ITT. The physiological mechanisms by which glucagon stimulates the cortisol secretion are still poorly explained $[12,16]$. Glycaemic fluctuation, which stimulates the synthesis of cortisol during the late fall in glycaemia, is among the most frequently mentioned hypotheses [17]. The cortisol peak after glucagon was observed at the $180^{\text {th }}$ $\mathrm{min}$, and blood the glucose peak recorded in our patients was at 30 minutes after glucagon followed by a decline in glucose concentrations at 120 minutes, as in several other studies [18-20].

Some studies have documented that a significant percentage of children with IGHD also have other anterior pituitary hormone deficiencies [2]. In adults, gonadotropin deficiency occurs as the second most common hormonal deficiency [21]. In our study, adrenal insufficiency was found in $25.6 \%$ of our cohort, which is similar to the results found by Tenenbaum et al. [22]. One of the most important studies reviewed 1366 children with IGHD; 11\% had ACTH deficiency [4]. Overall, $33 \%$ of the children were deficient in one or more hormones other than GH. In previous studies made by Rona and Maghnie et al., the prevalence of ACTH deficiency was between 6 and $26 \%[5,23]$. Exploring the adrenal axis in the diagnosis of GHD appears to be important, knowing that later on, in adulthood, those patients are at risk of developing other pituitary abnormalities [24]. A recent publication that examined a small number of adults with a history of childhood-onset IGHD found that $44 \%$ of those retested had a subnormal cortisol response to ITT [25]. This emphasises the interest of using a reliable test in assessing the adrenal axis in childhood.

In the understanding of this association between adrenal and somatotroph deficiencies, genetics plays a fundamental role, knowing that radiologic imaging may be normal. Most cases of IGHD and hypopituitarism are still considered sporadic, and genetic causes are being identified with increasing frequency. The developmental cascade that leads to normal pituitary development and function use some regulatory genes leading to the differentiation of the corticotroph cell line, which occurs fairly early during development, whereas somatotrophs differentiate near the end of pituitary development [26]. Mutations in the genes encoding the HESX1, PROP1, and PIT1 developmental transcription factors are associated with combined pituitary hormone deficiency diseases [27]. This sustains the hypothesis that ACTH deficiency is unlikely in the setting of normal pituitary anatomy with a normal TSH secretion [28].

In our study, we tried to explore the variability of gender and age on cortisol secretions. Our findings were that male patients had a higher cortisol peak and increment compared to female patients. Those findings are similar to other works aiming to study cortisol responses to GST with a comparison by gender and sex. In the same study, they demonstrated an inverse relation between age and cortisol response, suggesting that the use of a single age threshold across the entire paediatric age group is inappropriate, and that age and gender should be factors to be considered when interpreting the results of stimulation tests of the HPA axis in children [22]. Sexual dimorphism has been reported previously with respect to cortisol production and metabolism in adolescents [29] and older adults [30], with most adult studies showing higher levels in males as demonstrated in our cohort. However, we still need larger cohorts to consider interpretation of cortisol secretion considering gender and age.

\section{Conclusions}

Children with IGHD display a significant risk of developing additional pituitary deficiencies at the onset of diagnosis. The absence of structural pituitary abnormalities does not exclude 
the occurrence of additional pituitary deficits. Adrenal insufficiency can silently evolve years after the onset of IGHD if the correct cortisol cut-off is not determined. The current study identified a prevalence of adrenal insufficiency of $25.64 \%$, which could predict greater risk for children if untreated, especially because a substantial proportion of patients do not present clinical symptoms. Based on the above considerations, our adrenally insufficient patients in whom ITT was contraindicated

\section{References}

1. Dattani M, Preece M. Growth hormone deficiency and related disorders: insights into causation, diagnosis, and treatment. Lancet 2004; 363: 1977-1987. doi: 10.1016/S0140-6736(04)16413-1

2. Walvoord EC, Rosenman MB, Eugster EA. Prevalence of adrenocorticotropin deficiency in children with idiopathic growth hormone deficiency. J Clin Endocrinol Metab 2004; 89: 5030-5034. doi: 10.1210/jc.2004-0364

3. Myslek-Prucnal M, Bieniasz J, Noczynska A. [Observation of children with total or partial somatotropic pituitary hypofunction treated with growth hormone $(\mathrm{GH})$ ]. Pediatr Endocrinol Diabetes Metab 2010; 16: 33-38.

4. August GP, Lippe BM, Blethen SL, et al. Growth hormone treatment in the United States: demographic and diagnostic features of 2331 children. J Pediatr 1990; 116: 899-903.

5. Rona RJ, Tanner JM. Aetiology of idiopathic growth hormone deficiency in England and Wales. Arch Dis Child 1977; 52: 197-208.

6. Dattani MT. Growth hormone deficiency and combined pituitary hormone deficiency: does the genotype matter? Clin Endocrinol (Oxf) 2005; 63: 121-130. doi: 10.1111/j.1365-2265.2005.02289.x

7. Ach T, Hasni Y, Ben Abdelkarim A, et al. Concordance des tests d'hypoglycémie insulinique et au glucagon dans l'exploration du retard de croissance idiopathique. Annales d'Endocrinologie 2018; 79: 320.

8. Orme SM, Peacey SR, Barth JH, Belchetz PE. Comparison of tests of stress-released cortisol secretion in pituitary disease. Clin Endocrinol (Oxf) 1996; 45: 135-140.

9. Littley MD, Gibson S, White A, et al. Comparison of the ACTH and cortisol responses to provocative testing with glucagon and insulin hypoglycaemia in normal subjects. Clin Endocrinol (Oxf) 1989; 31: 527-533.

10. Shah A, Stanhope R, Matthew D. Hazards of pharmacological tests of growth hormone secretion in childhood. BMJ 1992; 304: 173-174.

11. Rao $\mathrm{RH}$, Spathis GS. Intramuscular glucagon as a provocative stimulus for the assessment of pituitary function: growth hormone and cortisol responses. Metabolism 1987; 36: 658-663.

12. Kappy MS, Drake A, Gao D, et al. Assessing adrenal function in primary care settings with a single sample subcutaneous glucagon test. J Pediatr 2006; 149: 682-686. doi: 10.1016/j.jpeds.2006.07.033

13. Karaca Z, Lale A, Tanriverdi F, et al. The comparison of low and standard dose ACTH and glucagon stimulation tests in the evaluation of hypothalamo-pituitary-adrenal axis in healthy adults. Pituitary 2011; 14: 134-140. doi: 10.1007/s11102-010-0270-3 could be safely identified with the GST, which allows the concomitant exploration of both adrenal and somatotroph axis. Longer duration of follow-up is associated with a higher risk of additional pituitary deficits, suggesting that hypopituitarism is a dynamic condition where new deficiencies can appear years after the initial diagnosis. Thus, it remains important to repeatedly look for additional pituitary hormone deficiencies.

14. Taieb A, Yosra H, Jihen M, Abdelkarim Asma B, Maha K, Molka C, et al. Cortisol cut-points for the glucagon stimulation test in the evaluation of hypothalamic pituitary adrenal axis. Endocr J 2018; 65: 935-942. doi: 10.1507/endocrj.EJ18-0147.

15. Abeillon-Du Payrat J, Raverot V, Simonet C, et al. Évaluation du test au glucagon comme alternative à l'hypoglycémie insulinique chez les patients à risque de déficit antéhypophysaire. Annales d'Endocrinologie 2014; 75: 264.

16. Hamrahian AH, Yuen KC, Gordon MB, et al. Revised GH and cortisol cut-points for the glucagon stimulation test in the evaluation of $\mathrm{GH}$ and hypothalamic-pituitary-adrenal axes in adults: results from a prospective randomized multicenter study. Pituitary 2016; 19: 332-341. doi: 10.1007/s11102-016-0712-7

17. Kawai K, Yokota C, Ohashi S, et al. Evidence that glucagon stimulates insulin secretion through its own receptor in rats. Diabetologia 1995; 38: 274-276.

18. Simsek Y, Karaca Z, Tanriverdi F, et al. A comparison of low-dose ACTH, glucagon stimulation and insulin tolerance test in patients with pituitary disorders. Clin Endocrinol (Oxf) 2015; 82: 45-52. doi: 10.1111/cen.12528

19. Ach T, Hasni Y, Ben Abdelkarim A, et al. Évaluation des temps de réponse du cortisol lors des tests de stimulation (hypoglycémie insulinique, synacthène $250 \mu \mathrm{g} / 1 \mu \mathrm{g}$, test au Glucagon). Annales d'Endocrinologie 2018; 79: 304.

20. Ach T, Hasni Y, Ben Abdelkarim A, et al. Intérêt et application pratique du test de stimulation au glucagon dans l'exploration corticotrope. Annales d'Endocrinologie 2018; 79: 285.

21. Preece MA. Diagnosis and treatment of children with growth hormone deficiency. Clin Endocrinol Metab 1982; 11: 1-24.

22. Tenenbaum A, Phillip M, de Vries L. The intramuscular glucagon stimulation test does not provide good discrimination between normal and inadequate ACTH reserve when used in the investigation of short healthy children. Horm Res Paediatr 2014; 82: 194-200. doi: 10.1159/000365190

23. Maghnie M, Triulzi F, Larizza D, et al. Hypothalamic-pituitary dysfunction in growth hormone-deficient patients with pituitary abnormalities. J Clin Endocrinol Metab 1991; 73: 79-83. doi: 10.1210/ jcem-73-1-79

24. Giavoli C, Bergamaschi S, Ferrante E, et al. Effect of growth hormone deficiency and recombinant hGH (rhGH) replacement on the hypothalamic-pituitary-adrenal axis in children with idiopathic isolated GH deficiency. Clin Endocrinol (Oxf) 2008; 68: 247-251. doi: 10.1111/j.1365-2265.2007.03029.x

25. Lange M, Feldt-Rasmussen U, Svendsen OL, et al. High risk of adrenal insufficiency in adults previously treated for idiopathic childhood 
onset growth hormone deficiency. J Clin Endocrinol Metab 2003; 88: 5784-5789. doi: 10.1210/jc.2003-030529

26. Cushman LJ, Showalter AD, Rhodes SJ. Genetic defects in the development and function of the anterior pituitary gland. Ann Med 2002; 34: 179-191.

27. Lamolet B, Pulichino AM, Lamonerie T, et al. A pituitary cell-restricted T box factor, Tpit, activates POMC transcription in cooperation with Pitx homeoproteins. Cell 2001; 104: 849-859.

28. Child CJ, Blum WF, Deal C, et al. Development of additional pituitary hormone deficiencies in pediatric patients originally diagnosed with isolated growth hormone deficiency due to organic causes. Eur J Endocrinol 2016; 174: 669-679. doi: 10.1530/EJE-15-1203

29. Wudy SA, Hartmann MF, Remer T. Sexual dimorphism in cortisol secretion starts after age 10 in healthy children: urinary cortisol metabolite excretion rates during growth. Am J Physiol Endocrinol Metab 2007; 293: E970-E976. doi: 10.1152/ajpendo.00495.2006

30. Keenan DM, Roelfsema F, Carroll BJ, et al. Sex defines the age dependence of endogenous ACTH-cortisol dose responsiveness. Am J Physiol Regul Integr Comp Physiol 2009; 297: R515-R523. doi: 10.1152/ajpregu.00200.2009 